\title{
Purification and determination of the modifying protein responsible for the post-synthetic modification of creatine kinase (EC 2.7.3.2) and enolase (EC 4.2.1.11)
}

\author{
A.A.J. van Landeghem ${ }^{\text {a. } *}$, J.B.J. Soons ${ }^{\text {a }}$, R.A. Wever ${ }^{\text {b }}$, \\ M.W.F.J. Mul-Steinbusch ${ }^{\mathrm{a}}$ and T. Antonissen-Zijda ${ }^{\mathrm{a}}$ \\ a Department of Clinical Chemistry, Faculty of Pharmacy, Utrecht State University, \\ St. Antonius Hospital, Nieuwegein and \\ ${ }^{b}$ Institute for Neurologv. Department of Neurological Chemistry, St. Radboud Hospital, Reinier Postlaan 4. \\ 6500 HB Nijmegen. (The Netherlands)
}

(Received June 28th, 1984; revision September 9th, 1985)

Key words: Modifying protein; $C K$ - conversion factor; Post-synthetic modification; Creatine kinase; Protein purification; Modifying activity; Enolase

\section{Summary}

The purification of a serum protein, responsible for the postsynthetic modification of CK and enolase, is described. A purification of about 1300 -fold could be reached after subsequent chromatography of human serum on DEAE cellulose and Sephacryl S-200 Superfine followed by affinity chromatography using antibodies against human serum albumin, $\mathrm{C} 3$ and $\mathrm{C} 4$ and against total human serum proteins. A recovery of $160 \%$ of modifying activity was found. The molecular mass and the isoelectric point of the modifying protein have been determined. It is concluded that the concentration of the modifying protein in human serum is $<210 \mathrm{mg} / \mathrm{l}$.

\section{Introduction}

As already described by us, the M-chain of creatine kinase (EC 2.7.3.2) undergoes a post-synthetic modification once the enzyme has arrived in circulation [1]. The existence of three MM- and two MB-forms can be explained by this modification. The changes introduced in the M-chain do not affect the molecular mass measurably

\footnotetext{
* Present address to which correspondence should be addressed: Department of Clinical Chemistry, St. Elisabeth Hospital, Hilvarenbeekseweg 60,5000 LC Tilburg, The Netherlands.
} 
[2], nor the immunological properties [2]. In addition, the post-synthetic multiple forms of the enzyme do have enzymatic activity [3]. The minor alterations in the CK molecule, however, result in a significant decrease in isoelectric point as the modification process proceeds [3]. The significance of this post-synthetic modification process is unknown. Probably, it plays a role in removing the enzymes from the circulation. The factor that induces the modification, turns out to be a serum protein, present in the blood of every healthy volunteer [1]. Recently, it has been claimed that this protein is a serum carboxypeptidase [4,5]. This paper describes the purification of this modifying protein from human serum and some of its characteristics.

\section{Materials and methods}

\section{Purification of the modifying protein}

Pooled human serum $(40 \mathrm{ml})$ was applied on a DEAE cellulose column $(300 \times 15$ mm, Whatman DE 52, Maidstone, UK), equilibrated in a $50 \mathrm{mmol} / 1 \mathrm{Tris} / \mathrm{HCl}$ buffer, pH 7.4, containing $50 \mathrm{mmol} / 1 \mathrm{NaCl}, 2 \mathrm{mmol} / 1 \mathrm{NaN}_{3}$ and $2 \mathrm{mmol} / 1$ mercaptoethanol (buffer A). Unbound protein was eluted with $300 \mathrm{ml}$ of this buffer with a flow rate of $1 \mathrm{ml} / \mathrm{min}$. The modifying protein was eluted from the column by linear salt gradient elution $(96-296 \mathrm{mmol} / 1 \mathrm{NaCl})$ between 170 and $220 \mathrm{mmol} / 1$ $\mathrm{NaCl}$ in a total volume of $35 \mathrm{ml}$ (flow rate $0.5 \mathrm{ml} / \mathrm{min}$; fraction size $5.0 \mathrm{ml}$ ).

The fraction containing the protein of interest was concentrated by about a factor 4 using PEG 6000 (Merck-Schuchart, München, FRG, no. 807491). Subsequently, this concentrated fraction was applied to a Sephacryl S-200 Superfine column $(1000 \times 25 \mathrm{~mm}$, Pharmacia Fine Chemicals, Uppsala, Sweden, no. S-200) equilibrated with buffer A. The column was developed with the same buffer (flow rate 1 $\mathrm{ml} / \mathrm{min}$; fraction size $5.0 \mathrm{ml}$ ). In further purification steps affinity chromatography using antibodies against human serum albumin (Sigma, St. Louis, MO, USA, no. A 0659), C3 and C4 (I.C.L., Fountain Valley, USA, nos. 84160 and 84156, respectively) and against total human serum protein (Behring Werke, Marburg, FRG, lot no. 100108 E) coupled on CNBr-Sepharose 4B (Pharmacia, no. 17-0430-01) was applied.

Coupling of the antibodies was performed according to the instructions of Pharmacia. The columns were eluted with a $100 \mathrm{mmol} / 1$ boric acid buffer $(\mathrm{pH} \mathrm{8.4)}$ containing $25 \mathrm{mmol} / 1$ di-sodium tetraborate, $500 \mathrm{mmol} / 1 \mathrm{NaCl}$ and $2 \mathrm{mmol} / 1$ $\mathrm{NaN}_{3}$.

\section{Purification of $C K-M M 3$}

Human heart tissue, obtained post mortem within $24 \mathrm{~h}$ of death, was minced and homogenized (three strokes of $1 \mathrm{~min}$ at full speed) at $0^{\circ} \mathrm{C}$ in $1: 4(\mathrm{w} / \mathrm{v}) 10 \mathrm{mmol} / 1$ Tris/ $\mathrm{HCl}$ (pH 7.4), containing $2 \mathrm{mmol} / 1 \mathrm{NaN}_{3}$ using a Virtis homogenizer (Virtis Company, NY, USA, model 6301-0001). After centrifugation (13000 $\times \mathrm{g}, 15 \mathrm{~min})$ the supernatant was stirred for $60 \mathrm{~min}$ at $4^{\circ} \mathrm{C}$ in $3 \mathrm{vol}$ of a DEAE cellulose suspcnsion (Whatman DE 52) (20 g DEAE cellulose in $600 \mathrm{ml} 50 \mathrm{mmol} / 1 \mathrm{Tris} / \mathrm{HCl}$, $\mathrm{pH} 7.0$ ), containing $\mathrm{NaCl}$ up to a concentration of $\mathrm{Cl}$ of $50 \mathrm{mmol} / 1$, i.e. buffer B. 
Subsequently, the mixture was applied to a glass fiiter and CK-MM3 was eluted with buffer B. Electrophoresis of the final preparation on agarose showed a single band of enzyme activity, indicating that CK-MM3 was free from other CK-forms.

Enzyme activity determinations were carried out on a LKB 8600 Reaction Rate Analyser (Bromma, Sweden) at $37^{\circ} \mathrm{C}$, using Baker reagents (Deventer, The Netherlands, nos. 3171, 3173, 3177).

\section{Measurement of modifying activity}

To measure modifying activity, samples containing the modifying protein were incubated with heart cytosol treated with DEAE cellulose (see 'purification of CK-MM3') containing CK-MM3 to a final concentration of $5000 \mathrm{U} / 1$ in the presence of $5 \mathrm{mmol} / 1 \mathrm{CaCl}_{2}$ at $37^{\circ} \mathrm{C}$ for $18 \mathrm{~h}$. After incubation the mixture was diluted twice with heat inactivated serum $\left(30 \mathrm{~min}\right.$ at $60^{\circ} \mathrm{C}$ ) and $1 \mu \mathrm{l}$ of this mixture, containing $2500 \mathrm{U} / 1$, was subjected to agarose electrophoresis (Corning Electroforese System, Palo Alto, CA, USA) as described earlier [6] but at pH 8.6. Gels were then incubated with $C K$ isoenzyme substrate reagent (Corning, no. 470069) and the NADPH fluorescence resulting from the MM-forms was detected with UV-light using the Cliscan scanner (Helena Labs., Beaumont, VA, USA). The concentration of each MM-form is expressed as a percentage of the total measured fluorescence. After that, the bands were stained [6]. The modifying activity was calculated as:

activity $=2[$ CK-MM1] $+[$ CK-MM2]

The calculated activity is only a relative measure and can be used to compare different preparations of modifying protein and to follow its purification.

\section{Estimation of molecular mass of the modifying protein}

After its partial purification, estimation of the molecular mass of the modifying protein was performed by gel permeation using an Ultrogel ACA-34 column $(380 \times 18 \mathrm{~mm}, \mathrm{LKB}$, no. $2204-440)$. The column was equilibrated with a 100 mmol/1 Tris/ $\mathrm{HCl}$ buffer $(\mathrm{pH} 7.4)$ containing $100 \mathrm{mmol} / 1 \mathrm{NaCl}$ and $2 \mathrm{mmol} / \mathrm{l}$ $\mathrm{NaN}_{3}$.

The modifying protein was eluted with the same buffer in fractions of $1 \mathrm{ml}$ with a flow rate of $5.3 \mathrm{ml} / \mathrm{h}$. Fractions were tested for modifying activity as described above. The elution volumes of reference proteins (Gel Filtration Calibration Kit, Pharmacia no. 10-c-007-02) were determined by absorbance measurements. The void volume was determined with blue dextran (Pharmacia). The Kaf values were calculated and plotted against the log molecular mass.

\section{Estimation of the isoelectric point of the modifying protein}

To estimate its $\mathrm{p} I$ value, the protein was partially purified on a Sephadex G-200 column $(600 \times 22 \mathrm{~mm}$, Pharmacia). The column was equilibrated with a $100 \mathrm{mmol} / 1$ Tris/ $\mathrm{HCl}$ buffer $(\mathrm{pH} 7.4)$ containing $500 \mathrm{mmol} / \mathrm{l} \mathrm{NaCl}$ and $2 \mathrm{mmol}^{\prime} / \mathrm{NaN}_{3}$. The modifying protein was eluted with the sante buffer at a flow rate of $7 \mathrm{ml} / \mathrm{h}$. The fraction size was $1.5 \mathrm{ml}$. Fractions containing relatively high activity were pooled 


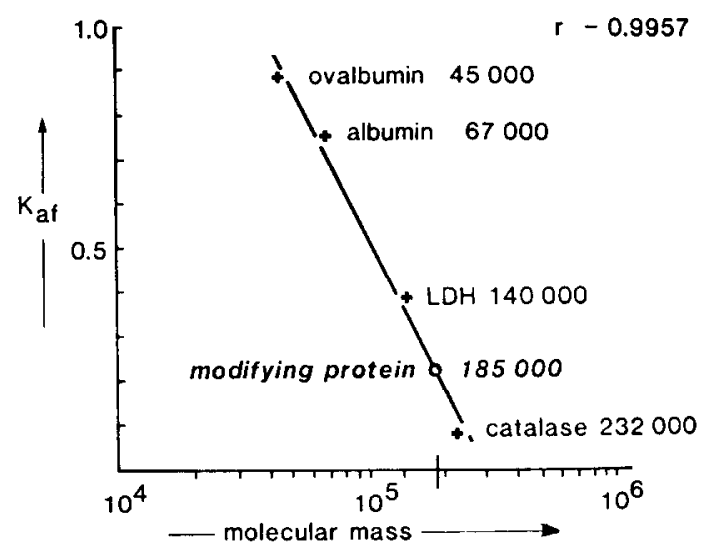

Fig. 1. Estimation of the molecular mass of the partially purified modifying protein by Ultrogel ACA-34 column chromatography.

and rechromatographed on Sephadex G-200 after dialysis against $100 \mathrm{mmol} / \mathrm{l}$ Tris $/ \mathrm{HCl}(\mathrm{pH} 7.4)$ containing $100 \mathrm{mmol} / 1 \mathrm{Na} / \mathrm{Cl}, 10 \mathrm{mmol} / 1 \beta$-mercaptoethanol and $2 \mathrm{mmol} / 1 \mathrm{NaN}_{3}$ and subsequent concentration in PEG 6000. At rechromatography the column was equilibrated and developed with this latter buffer (flow rate 7 $\mathrm{ml} / \mathrm{h}$; fraction size $1.5 \mathrm{ml}$ ). Fractions with the highest activity were pooled, dialysed against water and applied to an isoelectric focusing column ( $\mathrm{pH} 3.5-10$, LKB 8100). Before testing the focusing fractions $(1 \mathrm{ml})$ on modifying activity, the ampholines were removed using collodium membranes (Sartorius, Göttingen, FRG, no. SM13202).

\section{Results}

The molecular mass of the modifying protein was estimated at $185000 \pm 1200$ (SD) $(n=5)$ as shown in Fig. 1.

Testing the focusing fractions on modifying activity revealed a $\mathrm{p} I$ value of 4.35 for the modifying protein (Fig. 2). A similar $\mathrm{p} I$ value (4.30-4.40) was found in a focusing experiment ( $\mathrm{pH} 3.5-5)$ using a fraction after chromatography of serum on DEAE cellulose and Sephadex G-200, successively. Both properties, i.e. molecular mass and $\mathrm{p} I$ were used as a guideline for the isolation of the modifying protein. Table I shows a typical example of the results of the different steps in the isolation of the modifying protein. After the first step (DEAE cellulose), the specific activity increases dramatically resulting in a 150 -fold purification. The modifying activity of the DEAE cellulose eluate appeared to be 4 times higher than that of serum. After this first purification step albumin appeared to be the major contaminating protein (Fig. 3.1) due to its $\mathrm{p} I$ value of 4.7 [8], which is in the vicinity of that of the modifying protein (4.35). The second purification step was, therefore, based on scparation in molccular mass (albumin is 67000; modifying protcin is 185000 ). This second purification step resulted in a two-fold increase of the specific activity 


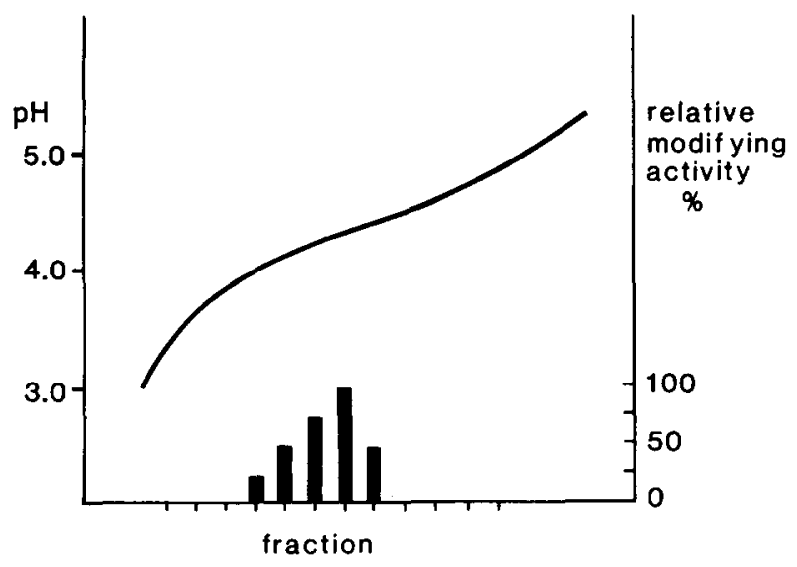

Fig. 2. Estimation of the $\mathrm{p} I$ value of the modifying protein by measuring the relative modifying activity of fractions obtained by isoelectric focusing on a LKB 8100 electrofocusing column. Conditions: ampholines $\left(5 \%\right.$ in a sucrose density gradient) $\mathrm{pH} 3-5,65 \mathrm{~h}, 2^{\circ} \mathrm{C}$. Current, voltage and power (LKB power supply 2103) limited at $5 \mathrm{~mA}, 700 \mathrm{~V}$ and $1 \mathrm{~W}$, respectively.

although $>50 \%$ of total activity was lost, possibly as a result of adsorption to column material due to the very low protein concentration of the sample.

After these two steps, a 300 -fold purification could be reached. However, agarose electrophoresis (Panagel Electroforesis system, Worthington, Freehold, USA, no. 0047601) and SDS-PAGE (using the Protean Double Slab Electrophoresis Cell from Biorad, Richmond, CA, USA no. 165-1420) showed a number of proteins still

\section{TABLE I}

Purification of the modifying protein

\begin{tabular}{lcccll}
\hline & $\begin{array}{l}\text { Vol } \\
(\mathrm{ml})\end{array}$ & $\begin{array}{l}\text { Protein } \\
(\mathrm{mg})\end{array}$ & $\begin{array}{l}\text { Spec } \\
\text { act } \\
\left(\mathrm{MU}^{\mathrm{a}} / \mathrm{mg}\right. \\
\left.\text { protein }^{\mathrm{b}}\right)\end{array}$ & $\begin{array}{l}\text { Recovery of } \\
\text { modifying } \\
\text { act } \\
(\%)\end{array}$ & $\begin{array}{l}\text { Purification } \\
\text { factor }\end{array}$ \\
\hline Serum & & & 0.14 & 100 & \\
DEAE cellulose & 30.0 & 2800 & 21.6 & 405 & 150 \\
PEG 6000 & 9.5 & 74.2 & 21.8 & 405 & 150 \\
Sephacryl & 27.0 & 17.2 & 39.3 & 169 & 275 \\
PEG 6000 & 2.5 & 16.0 & 42.3 & 169 & 295 \\
Anti-HSA & 2.5 & 10.7 & 63.2 & 169 & 440 \\
Anti-C3 & 2.5 & 9.3 & 72.8 & 169 & 510 \\
Anti-C4 & 2.5 & 8.5 & 79.5 & 169 & 555 \\
Anti-total & 2.5 & 3.4 & 184.0 & 156 & 1285 \\
$\quad$ human serum & & & & & \\
\hline
\end{tabular}

a $1 \mathrm{MU}$ (modifying unit) = modifying activity presents in $100 \mu 1$ of the serum from which the modifying protein is purified.

b Protein was determined by the Lowry method [7]. 


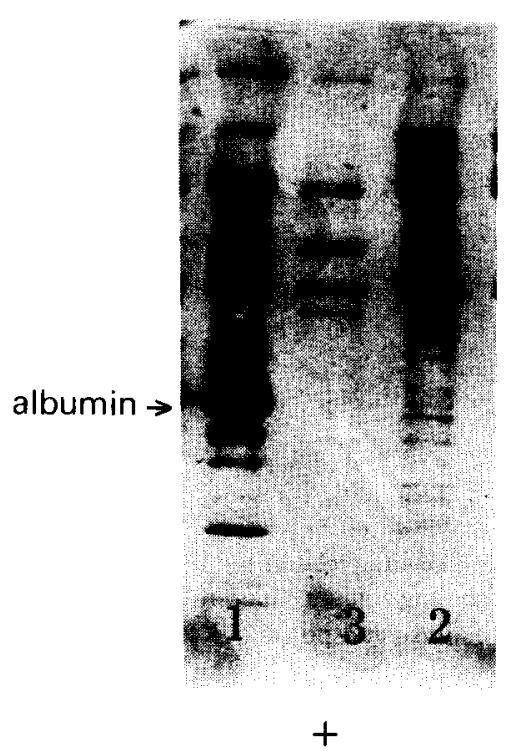

Fig. 3. SDS-PAGE of samples containing modifying activity (see Table 1). Conditions; gradient 4-18\%, cross-link 2.6\%, pH 9.0. Electrophoresis according to Biorad with the Biorad Protein Cell System, in the upper gel at $200 \mathrm{~V}$ and in the lower gel at $300 \mathrm{~V}$ for $6 \mathrm{~h}$ at $4^{\circ} \mathrm{C}$. Coomassie Brilliant Blue Stain. 3-1, After DEAE chromatography; 3-2, after DEAE and Sephacryl S-200 chromatography; 3-3, after affinity chromatography with anti-HSA of preparation 3-2.

present (Fig. 3.2) Affinity chromatography on an anti-human serum albumin column removed the last albumin as could be demonstrated by SDS-PAGE (Fig. 3.3) and radial immunodiffusion (endoplates low level, Kallestad, Austin, TX, USA, no. 567). Immunoelectrophoresis of this sample showed 3 precipitation lines against anti-total human serum proteins (data not shown). One of these lines could be demonstrated to be $\mathrm{C} 3$. Determination of $\mathrm{C} 3$ and $\mathrm{C} 4$ showed that about $20 \%$ of the total protein concentration was due to these two proteins, which could be totally removed by affinity chromatography (Table I). Identification of the other two lines has failed so far. Finally, affinity chromatography was performed with antiserum against total human serum protein. In this way, about $60 \%$ of the remaining impurities could be removed without loss of modifying activity and a 1300 -fold purification could be reached. No modifying activity could be demonstrated in the bound proteins eluted from this column. Saturation of the column could be ruled out by experiments with diluted samples.

\section{Discussion}

We described a method for purifying the serum protein which is responsible for the post-synthetic modification of creatine kinase. A final purification of about 1300 -fold and a yield of $156 \%$ could be reached. Removal of more than $95 \%$ of the 
serum proteins, which can possibly inhibit the modifying activity, and of other eventual disturbing factors may be an explanation for this $>100 \%$ recovery. The same phenomenon was recently described by Edwards and Watts [9]. Addition of albumin to the modification test medium resulted in substantial inhibition of modifying activity (data not shown) which supports our supposition.

The molecular mass of the modifying protein as estimated at 185000 agrees fairly well with the 190000 reported by Falter et al [8] for their partially purified ' $\mathrm{CK}$ conversion factor'.

Assuming that in the first purification step (DEAE cellulose) no modifying protein has been lost, the final recovery can be calculated to be $42 \%$. If all the protein recovered after the last purification step, i.e. $3.4 \mathrm{mg}$, represents the modifying protein, the concentration in human serum will be $210 \mathrm{mg} / \mathrm{l}$. The fact that the modifying protein cannot be bound by immobilized antibodies against total human serum proteins suggests that this antiserum does not contain antibodies against the modifying protein. The concentration of the protein in human serum is possibly too low to raise antibodies. In a final purification scheme the steps using antibodies against $\mathrm{C} 3$ and $\mathrm{C} 4$ may be omitted as these antibodies will be present in the antiserum against total human serum proteins.

Recently, a quantitative method has been described to estimate the amount of the CK-conversion factor in human serum [5,10]. That method is based on calculation of the decrease per unit of time of the percentage of unmodified M-chains. To judge the increase of specific activity in the course of the purification procedure, we used a similar but simpler method, calculating a relative modifying activity from the percentage of CK-MM2 and CK-MM1 measured after only one period of incubation, i.e. after $18 \mathrm{~h}$. We assumed that a similar modification occurs in both subunits of the CK molecule and that the modifying protein has to develop its activity once to modify MM3 to MM2 and twice to modify MM3 to MM1. This leads to the rather speculative formula given in 'Materials and Methods'.

Meanwhile, Wevers et al [11] have found that the action of the modifying protein is not restricted to the CK M-chain. Human alfa-alfa enolase is also modified by the same protein. Therefore, the more general name 'modifying protein' has been proposed [11] instead of the name 'CK-conversion factor' as used by Falter et al [10] which is confined to creatine kinase. Whether there are more enzymes modified by this protein are questions under current investigation.

\section{References}

1 Wevers RA, Delsing M, Klein Gebbink JAG, Soons JBJ. Post-synthetic changes in creatine kinase isozymes (EC 2.7.3.2). Clin Chim Acta 1978; 86: 323-327.

2 Wevers RA. Thesis, State University Utrecht, The Netherlands, 1981.

3 Wevers RA, Wolters RJ, Soons JBJ. Isoelectric focusing and hybridisation experiments on creatine kinase (EC 2.7.3.2). Clin Chim Acta 1977; 78: 271-276.

4 Edwards RJ, Watts DC. Human 'creatine kinase conversion factor' identified as a carboxypeptidase. Biochem J 1984; 221: 465-470.

5 Perryman MB, Knell JD, Roberts R. Carboxypeptidase - catalyzed hydrolysis of C - terminal lysine: mechanism for in vivo production of multiple forms of creatine kinase in plasma. Clin Chem 1984; 30: 662-664. 
6 Wevers RA, Olthuis HP, Van Niel JCC, Van Wilgenburg MGM, Soons JBJ. A study on the dimeric structure of creatine kinase (EC 2.7.3.2). Clin Chim Acta 1977; 75: 377-385.

7 Lowry OH, Rosebrough NJ, Farr AL, Randall RJ. Protein measurement with the Folin phenol reagent. J Biol Chem 1951; 193: 265-275.

8 Falter H, Michelutti L, Mazzuchin A, Whiston W. Studies on the sub-banding of creatine kinase MM and the 'CK conversion factor'. Clin Biochem 1981; 14: 3-7.

9 Edwards RJ, Watts DC. Tetrathionate-blocked creatine kinase as a substrate for human plasma 'creatine kinase conversion factor'. Clin Chim Acta 1983; 133: 275-283.

10 Falter $\mathrm{H}$, Michelutti L, Mazzuchin A, Whiston W. An assay for creatine kinase conversion factor. Clin Biochem 1982; 15: 200-205.

11 Wevers RA, Boegheim JPJ, Hommes OR, Van Landeghem AAJ, Van der Stappen JWJ, Soons JBJ. A study on postsynthetic modifications in alfa-alfa enolase (EC 4.2.1.11) brought about by a human serum protein. Clin Chim Acta 1984; 139: 127-135. 